\title{
Culture is a luxury in Latin America*
}

La cultura es un lujo en América Latina

\author{
SANTIAgo ACEREnZA** \\ NÉSTOR GANDELMAN***
}

\begin{abstract}
In this paper we use micro-data from income and expenditure surveys for seven Latin American countries. We estimate Engel equations and present stylized facts regarding cultural spending. Culture activities are a key indicator of a society development and therefore cultural spending decisions are illustrative of how individuals behave and interact within society. We find that culture behaves as a luxury good with income (expenditure) elasticities of cultural spending around 2. Further, we estimate elasticities for three components of cultural spending: spending in cinemas, theaters, music and dancing performances, spending in sports events and spending in other cultural activities. These expenditure elasticities are remarkably similar, also near 2. Additionally, we find that cultural spending is larger in urban areas, larger for households where the household head is a female and larger in household with more members but lower per child as the number of children increases. We find that cultural spending is positively correlated with the education level of the household head and that older household heads allocate a lower share of the budget to culture.
\end{abstract}

Key words: Culture, income and expenditure surveys, Engel equations, elasticity, Latin America.

JEL Classification: D12, D13, Z11.

\footnotetext{
* We thank the editor and an anonymous reviewer for very detailed and valuable comments and suggestions on the original manuscript. All errors and omissions are responsibility of the authors.

** Iowa State University. Email: acerenza@iastate.edu

*** [Corresponding author] Universidad ORT Uruguay. Email: gandelman@ort.edu.uy
}

Received: September, 2017. Accepted: September, 2018. 


\section{Resumen}

En este trabajo utilizamos microdatos de encuestas de ingresos y gastos para siete países de América Latina. Estimamos ecuaciones de Engel y presentamos los hechos estilizados respecto del gasto cultural. Las actividades culturales son un indicador clave del desarrollo de la sociedad y, por tanto, las decisiones de gasto cultural son ilustrativas de cómo los individuos se comportan e interactúan dentro de ella. Encontramos que la cultura se comporta como un bien de lujo con elasticidades de ingreso (gasto) en el entorno de 2. Estimamos elasticidades para tres componentes del gasto cultural: gasto en cines, teatros, espectáculos de música y baile, gasto en eventos deportivos y gasto en otras actividades culturales. Estas elasticidades son notablemente similares entre sí, también cerca de 2. Adicionalmente, encontramos que el gasto cultural es mayor en áreas urbanas, mayor para hogares con jefe del hogar femenino y mayor en hogares más numerosos, aunque el gasto por niño es menor en los hogares con más hijos. Encontramos que el gasto cultural está correlacionado positivamente con el nivel de educación del jefe de hogar y que los jefes de familia de mayor edad asignan una menor proporción de su presupuesto a la cultura.

Palabras clave: Cultura; encuestas de ingresos y gastos, Ecuaciones de Engel, elasticidad, América Latina.

Clasificación JEL: D12, D13, Z11.

\section{INTRODUCTION}

Households allocate their budget into many kinds of goods and services. Academicians and policy makers have given substantial attention to expenditure in food (as a determinant of nutrition levels) and in education and health (as proxies for human capital investments). Although it can also be considered an important determinant of human development, cultural spending has received considerably less attention. Many cultural goods are publicly provided and are free of charge (e.g. some museums have no entrance fee), but many involve private spending. Even considering public sector transfers, privately provided cultural goods depend mostrly on household's decisions to allocate funds to them. A better understanding of demand for cultural activities would be useful both to policy makers and to private sector actors involved in culture. In this paper, we aim at using income and expenditure surveys to characterize private spending in cultural goods in Latin America. We address the association of cultural spending with key socio-demographic indicators and test whether culture is a necessity or a luxury good.

Cultural spending has an impact on the way individuals interact, on the labor market perspectives and on their overall subjective wellbeing. Although there is a lively debate representing differences as to magnitudes, methods of 
measurement, the degree of marginal relevance (and hence required public policy intervention), and the mix between instrumental and intrinsic benefits, most researchers would agree that cultural activities yield positive externalities for society as a whole. This externality has been argued to justify government subsidies (Fullerton 1992 among others). More cultural spending, ceteris paribus, does not have only direct positive effects on economic outcomes. It also has indirect effects through other variables. For example, Reeder and Brown (2005) show that recreation and tourism development contribute to well-being, increases local employment and wage levels, reduces poverty and improves education and health in rural US counties. Torjman (2004) states that cultural and recreational programs reduce crime among young people. Culture also has effects on elderly health. Silverstein and Parker (2005) show that elderly increasing their activity participation in leisure activities tended to perceive an improvement in their quality of life. Leisure can also improve happiness among Alzheimer dementia patients (Schreiner et al., 2005), facilitate independency among the elderly (Searle et al., 2002), lower depression symptoms and increase psychological well-being (Dupuis and Smale, 1995), help coping with life stress (Coleman and Iso-Ahola, 1993), increase psychological wellbeing in adolescents (Garst et al., 2001) and improve academic performance (Burton et al., 2000).

Besides its impact in present life, consumption of cultural goods has a temporal characteristic. Past consumption levels influence subsequent ones (Ateca, 2007 among others). This has implications for business cycles variations in culture demand. During economic downturns the demand for all normal goods is reduced. The demand for luxury goods is reduced even in a higher proportion than the general reduction in household income. This way, if cultural spending behaves as a luxury, short run recessions can have longer term impacts of worsened cultural activity. The economies of Latin America have suffered in the past from considerable growth instability. The impact of this on culture has not been previously considered in Latin America ${ }^{1}$. In this paper, we report estimates showing that the expenditure elasticity of culture in Latin America is large (around 2) and therefore governments should pay special attention to how they support cultural activities especially in recession years.

The paper proceeds as follows. In section 2, we put our paper into the broader literature and discuss our contribution. Section 3 presents the data sources, the working definitions of consumption and cultural spending and the methodology to estimate Engel curves. Section 4 reports the results and section 5 concludes.

\footnotetext{
The sensitivity of the arts, as a major form of discretionary entertainment spending, to business cycles is well-recognized by studies based on developed countries. Nevertheless, the emphasis has been more on the adverse effects of recessions on government grants and other such support, rather than on private sector demand. See Alliance for the Arts (2009), Woronkowicz (2015), Mermiri (2011) and Skinner et al. (2009).
} 


\section{BRIEF LITERATURE REVIEW AND OUR CONTRIBUTION}

The analysis of cultural spending is part of the broader study of cultural economics. The modern literature on cultural economics started with Baumol and Bowen (1966) where they introduced the economics of arts and museums. They present an empirical study of the finance, costs and prices, in theaters, orchestras, opera and ballet. Also, they studied employment and labor income of artists in the US. Peacock (1969) continued the economic analysis of museums, adding the study of built heritage.

The focus on cultural economics has been on the study of its supply and demand sides. On the supply side Throsby (1994) and Throsby (2001) developed a model of labor artist provision. This produced the artists' work preference model that was later expanded by Casacuberta and Gandelman (2012) to include consumption, leisure and art work in the artists' preferences. Considering both the demand and supply side and using an institutional approach Frey (2002) studied the behavior of private museums. Using also supply and demand analysis Moore (1968) studied the American theatre, Sprays (1962) studied the evolution of the cinema market, Halsey (1972), Browning and Sorrell (1954) and Throsby and Withers (1979) studied consumers' choice among recreational activities such as opera and ballet. Another set of papers from both supply and demand side focused on the pricing and consumption of art works (see for instance Frey and Pommerehne 1989, Agnello and Pierce 1996, McCain 1995 and Ginsburgh and Jeanfils 1999).

To connect our contribution to the previous literature it should be noted that the issue whether culture is a luxury or necessity good implies studying the demand side of cultural markets. In his careful literature review, Seaman (2006) reports 29 empirical studies that estimated price and/or income elasticities in the performing arts (e.g. Withers, 1980, Bonato et al., 1990, Felton, 1992). Some of the literature has focused on modeling attendance or number of subscribers to cultural activities. For instance, Kelejian and Lawrence (1980) estimated the demand for New York City Broadway Theater. Cameron (1990) studied the demand for movie theaters in the United Kingdom and found positive income elasticity in a range between 1.4 to 1.5 and a negative own-price elasticity ranging between -1.5 to -1.6 . Gapinski (1984) estimated the demand for attendance to Shakespeare plays in Britain from 1965 to 1981 and found an own price elasticity of -0.66 and an income elasticity of 1.32 . On a posterior work, Gapinski (1986) studied the behavior of demand for live arts including possible substitute activities (movies, reading and other recreation activities). Using data of both residents and tourists in London from 1971 through 1983, he found price elasticity between -0.81 and -0.05 and income elasticity between 0.1 and 1.21 . On the same line, Felton (1992) studied the demand of performing arts using a panel from US companies and reported price elasticity between -0.95 and -0.13 . Also within this literature, Fernández Blanco and Baños Pino (1997) studied the demand of cinema in Spain from 1968-1992 and found a long-run elasticity for the own price of -3.04 and an income elasticity of 1.27. Zieba (2009) using 
data from 178 German public theatres between 1965 and 2004 found a price elasticity between -0.27 and -0.43 and income elasticity between 0.60 and 1.22. The referenced studies all focus on single market analysis and elasticities correspond to narrow definitions of cultural participation.

Differences in the results may in part be due to the time intensity of consuming the live performing arts (as in live sports), whereby the opportunity cost of time that increases with rising wages generates a substitution effect that mutes the overall income elasticity results. While not done often, Withers (1980) attempted to decompose income elasticity into a pure income effect partly offset by real leisure price substitution effect. While Withers' results still supported the arts as a leisure good, a subsequent attempt to directly address and control for the effect of time costs on US symphony concert demand found a negative effect of the wage rate as a proxy for the value of time, and a less than unitary income elasticity (Ekelund and Ritenour, 1999). Seaman (2006) also observed that there can be notable differences in estimated income elasticities depending on the level of aggregation of the data (e.g., individual theater vs. all theaters).

Methodologically, our paper is closer to other studies within the demand side approach that are based on households' expenditure surveys. Using data from the US consumer expenditure survey from 1988-1989, Dardis et al. (1994) estimated a Tobit model of absolute household expenditure in attendance to theaters and museums. They find that the level of income and the number of adults has a positive correlation with cultural expenditure, while the number of children in the house, and living in rural areas, have a negative effect. They found an income elasticity of 1.71 for salary income while for the non-salary income they found a much lower elasticity of 0.72 . Bernat et al. (2012) analyzed the cultural demand in the city of Cali using a household expenditure survey. The estimated Engel curve implied an incomeexpenditure elasticity of cultural spending of 0.99. Additionally, they report that the share of cultural spending is positively correlated with the number of working household members and with the level of education, while is negatively correlated with the number of children of less than six years old. Diniz and Machado (2011), using the Survey of Family Budget of IBGE from Brazil during 2002-2003, studied the per capita household expenditure on cultural goods using a censored least absolute deviation quintile method. They find that cultural consumption is negatively correlated with being a male and with age while it is positively correlated with education of the household head, per capita income, number of household members and per capita indirect expenditures of the household.

Summing up the literature, there is no consensus of whether culture is a luxury or a necessity good. As reviewed, income elasticities for cultural goods have been found to be positive but there is significant variety in the point estimates with some studies reporting elasticities above 1 and some reporting elasticities below 1 . The issue of whether culture is a necessity or a luxury is not closed. 
This paper is based on examining expenditure surveys and generating expenditure elasticities in contrast to much of the cited literature that focuses on generating income (and price and other demand) elasticities. This distinction is subtle but requires some clarification. For example, under the assumption of constant prices, an income elasticity of say 1.5 whereby a $10 \%$ increase in income generates a $15 \%$ increase in the quantity demanded of a cultural good (for example measured as attendance at performances) will also generate an increase of $15 \%$ in expenditures, for an income elasticity of cultural expenditures of 1.5 (defined as the percentage change in cultural expenditures divided by the percentage change in income). While the closeness of income elasticity and expenditure elasticity justifies the somewhat fluid movement between those two measures, they are not the same and data availability may facilitate the use of one or the other. Household surveys report various forms of income but tend to fail to adequately capture income sources from capital markets (e.g. dividends or capital gains). Total household expenditure is therefore a better independent variable to use, and the elasticities derived in this paper are hence technically household expenditure elasticities of cultural expenditures, or the percentage change in cultural spending divided by the percentage change in household expenditures. If household saving rates are homogenous, the word 'budget' can also be substituted for 'household expenditures.' In any case, since the denominator in such elasticity equations is not household income, we are not technically deriving income elasticities, but instead, we are deriving expenditure elasticities. Nevertheless, the same core implication exists: just as with income elasticities, if the household expenditure elasticity of cultural spending exceeds one, cultural spending will increase as a portion of total household spending for higher total spending households, and cultural spending would be a luxury good.

More in general, we analyze the relationship between cultural expenditure and basic demographic characteristics. There is a difficulty in gathering good detailed data on cultural spending and household characteristics. The consequence is that results are often partial and methodologically very heterogeneous. Some of these problems are not solved in this paper, nevertheless, we contribute to the literature in applying a homogenous approach to a wide set of countries. We go beyond single cases studies and contribute to the literature by estimating Engle curves for seven Latin American countries (LAC). We focus on data homogenization and apply an invariant methodology to evaluate the consistency of the results. As far as we know this is the first multi-country cultural expenditure study not based in the developed world.

We provide evidence that in Latin America cultural spending behaves as a luxury. We report that the median allocation in cultural goods in the countries studied is 0 , therefore, we had to evaluate the elasticities at the mean cultural spending conditional on positive spending.

We find an expenditure elasticity of cultural goods of 1.9 for LAC. We report elasticities by country and found them to range from 1.7 (Brazil) to 2.9 (Bolivia). We also estimate separate elasticities for three components a cultural expenditure (spending in cinemas, theater, music and dancing events, spending 
in sports events and spending in other cultural activities) and found them to be remarkably similar $(2.0,1.9$ and 2.0 respectively). We cannot reject the null hypothesis that none of these categories of expenditure elasticities is as high as 2.0.

Our estimates suggest larger elasticities than other studies. Our expenditurebased approach implies a broader look at society where inequality in cultural spending is huge as reported here in Gini indexes. This inequality in cultural spending is likely a more acute problem in developing than in developed countries. As such, larger elasticities were to be expected in our study.

\section{DATA AND METHOdology}

\section{a. Data sources and data recollection mechanisms}

Countries gather income and expenditure surveys at least every ten years or so as an input in the elaboration of the consumption basket to be followed by the Consumer Price Index. Given the objective of these surveys, data on consumption expenditure is very disaggregated.

For this paper, micro data comes from seven LAC countries: Bolivia, Brazil, Chile, Ecuador, Mexico, Paraguay and Uruguay. Survey coverage includes representative samples from both urban and rural settings in most countries. The survey of Chile is the only one that covers only urban areas. Bolivia, Brazil, Ecuador, Mexico, Paraguay and Uruguay cover both rural and urban areas. Table A1 in the appendix presents the data sources.

The survey time periods range from 2003-2004 (Bolivia) to 2014 (Mexico). The best-case scenario would be to have information for all countries at the same moment in time and in the same phase of the business cycle. Unfortunately, this is not possible in a multi-country study as in this paper. Therefore, we acknowledge that our contribution of examining multi-country data and deriving results for seven different developing Latin American countries has some limitations due to the common problem of confronting some inter-country data differences.

Acerenza and Gandelman (2019) in their analysis of educational spending in Latin America explain that expenditure and income surveys tend to use two types of recollection mechanisms to gather expenditure information: interviews and diaries. All countries use interviews for the less frequent and high amount expenses that are assumed to be correctly estimated by an informed household member. By contrast, the diary approach is usually used for household spending that is more frequent and in smaller amounts over a seven-day period. In some countries, there are two diaries: one to compute the common household expenses and another to compute each household member's own expenses.

There are differences in the time frames within and between surveys. The following time periods previous to the date of recollection are usually considered: a) one weak, b) one month, c) three months and d) one year. Most frequently, option a) is used for food and cleaning item expenses. Option b) recollects 
information of expenses such as clothes and transportation. Option c) recollects information of things such as maintenance of household equipment. Finally, d) gathers information usually on durable goods, educational and housing expenses. We transform all measures into annual estimates.

\section{b. Definition of cultural spending in absolute and relative terms}

In this paper we focus on spending in cultural activities. Cultural participation in activities that have no cost are not reflected in our statistics. For us there is no way to offer a distinction between "cultural experiences" and cultural spending. We understand this is a methodological definition that may differ from other studies. Therefore, the focus on spending should be kept in mind when considering the reported results.

We consider the following disaggregation for household cultural spending: expenditure in cinema, theatre and musical events, spending in sports events (such as tickets) and a residual category including other kind of cultural expenditures (such as libraries, art galleries and visits to museums and national parks among others).

To compute the ratio of cultural spending to total consumption we define consumption expenditure in a broad sense and include all forms of consumption (paid or home produced). We define total consumption spending as everything consumed by the household whether bought, obtained as a gift or home produced. Often, national statistics agencies impute the rental value of homeowners as a form of consumption. They estimate it or ask directly to homeowners how much they would have to pay as concept of rent to live where they do. We exclude this value from our working definition of total consumption as it does not constitute a form of direct spending.

\section{c. Engel curves}

The econometric estimations of Engel curves for various good and services have been performed in microeconomic applied research since Working (1943) and Leser (1963). These authors showed a stable association between the expenditure share of food consumption and the logarithm of income. Later research has specified functional forms beyond the linear case that allowed for more curvature than the Working-Leser model. The basic Engel estimation begins with the definition of relatively homogeneous demographic groups to which various estimations techniques can be applied. In Blundell (1998) there is a good review of how the literature on consumer demand and household allocation developed. Methodologically, the functional form adopted by the Engel equation must not violate the adding-up condition ${ }^{2}$. This is consistent with the

2 The sum of total expenditure elasticities weighted by the corresponding budget shares of each expenditure must add up to unity. 
standard assumption that consumption takes place at the upper boundary of the household budget set.

The Working-Leser typical functional form is:

$$
w_{i}=\alpha+\beta \ln \left(\frac{x_{i}}{n_{i}}\right)+\gamma \ln n_{i}+\varphi z_{i}+\mu_{i}
$$

where $w_{i}$ is the budget share of cultural expenses of the $\mathrm{i}^{\text {th }}$ household, $x_{i}$ is the total expenditure of the household ${ }^{3}, n_{i}$ is the household size, $z_{i}$ is a vector of other household socio-demographic characteristics as education and gender of the household head and dummies for urban or rural residence. $\mu_{i}$ is the error term capturing unobserved heterogeneity that is assumed to be well behaved. The expenditure elasticity of cultural spending is $1+\frac{\beta}{w_{i}}$. This functional form allows the elasticity to vary by the share of cultural expenditure but does not allow the good to be a necessity $(\beta<0)$ for some households and a luxury $(\beta>0)$ for others. The expenditure elasticity must be valued at some point in the share of cultural spending distribution (i.e. at some $w$ ). Given that for most of the population cultural spending is 0 (as shown in the next section), we valued the elasticity at the mean share for those that have positive cultural spending.

The first estimations of Engel equations were performed for food expenditure simply using OLS. For other types of expenditure, like education, culture and health there is the problem of a substantial number of zero expenditure for many households. The traditional solution for this censoring problem is the estimation of a Tobit model ${ }^{4}$.

\section{Results}

\section{a. Descriptive statistics}

We begin this descriptive section reporting aggregated averages ${ }^{5}$. In Figure 1, Panel A shows that the average annual household spending in cultural goods is $\$ 79$ (PPP adjusted dollars of 2014). As we can see in this first panel, Mexico (\$133) is the country that spends more in absolute terms while Ecuador (\$ 38) the least. Panel B, presents the average ratio of cultural spending. In all LAC

3 In some formulations of the Working Leser framework total expenditure $x_{i}$ is used instead of per capita expenditure $\left(\frac{x_{i}}{n_{i}}\right)$ as we do in this paper.

4 A similar framework is used by Acerenza and Gandelman (2019) for education and Gandelman, Serebrisky and Suarez-Alemán (2018) for transportation.

5 Through the paper when we speak of LAC average we refer to a population weighted average. 
FIGURE 1

AVERAGE ANNUAL CULTURAL EXPENSES BY COUNTRY

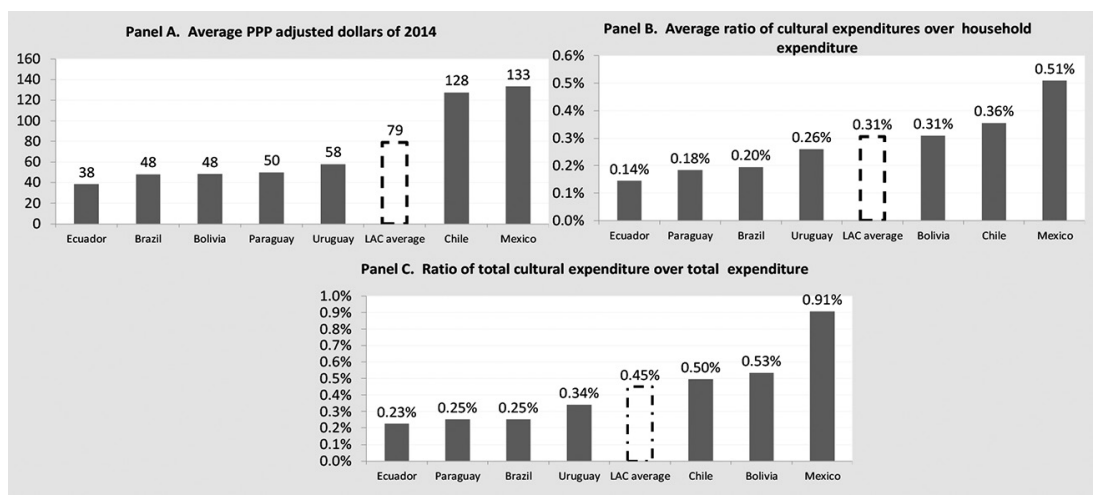

countries it represents a very low proportion of the household budget, being on average $0.31 \%$. Mexico $(0.51 \%)$ is the country whose households spend a largest share of their budgets on cultural activities, followed by Chile $(0.36 \%)$, while Ecuador (0.14\%) has the lowest share.

Panel B and Panel C look similar, but they do not report the exact same information. The average of the ratios (Panel B) gives the same weight to each household while in the ratio of averages (Panel C) the rich account for a larger proportion of the denominator. If rich people spend a higher share of their budget on culture than the poor, then the ratio of the average spending to average total spending will be higher than the average of household ratios. This phenomenon occurs in every country. This is an interesting pattern and a first insight into a luxurious condition of cultural spending.

The presentation of the different forms of cultural spending varies between surveys. We try to disaggregate cultural spending into its components in a way that would allow to have some common ground for all countries. We ended up with three subcomponents: spending in cinemas, theaters, music and dancing events, spending in sports events and spending in other cultural activities. They account for $76 \%, 7 \%$ and $17 \%$ of the average cultural spending in LAC (see appendix A2 for the results by country).

Table 1 presents inequality summary statistics. A significant difference exists between mean and median expenditures (in absolute terms and relative to total consumption). At the median, cultural expenditure is 0 . This means that more than half of the household in the region make no private spending of any sort in cultural goods. This is present in all the countries of the sample and is suggestive of a right skewed distribution. Cultural spending is extremely unequal along the entire sample with Gini indicators ranging between 0.92 to 0.97 . These statistics are about the double of the Gini indicators for total consumption and income computed with the same data. We also report Gini indexes from the World Bank as a check of the quality of the data. 


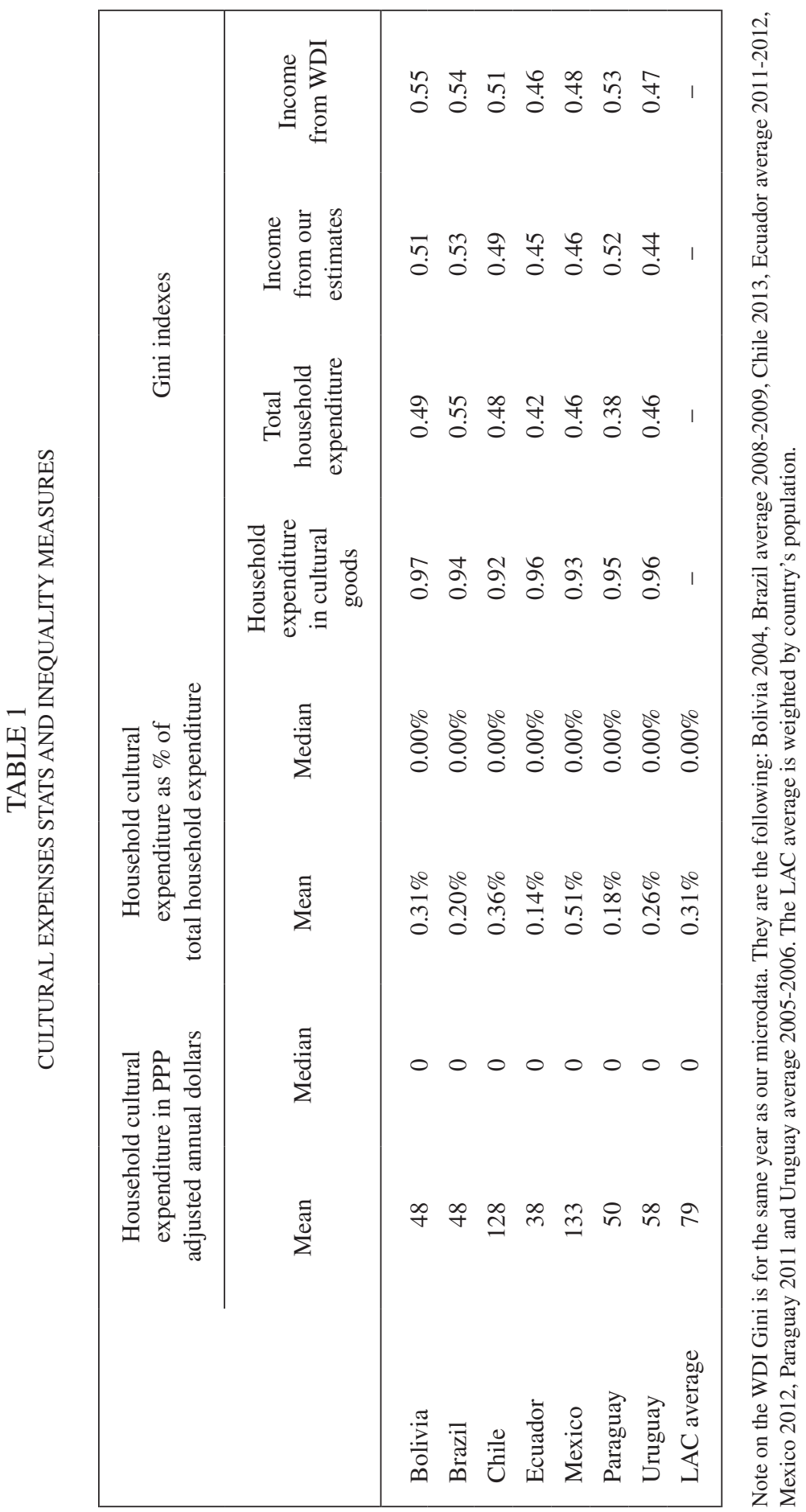


On Figure 2, we disaggregate cultural spending by quintile groups. While it is natural to think that the rich spend more in absolute terms than the poor (Panel A) it is not so obvious as a share of their consumption budgets (Panel B). Those in the higher quintile spend annually $\$ 270$ vs. \$ 31 for the median group and $\$ 3$ for the poorer group. If the expenditure elasticity of cultural spending were 1 , an increase of $\mathrm{x} \%$ in total spending would translate into an $\mathrm{x} \%$ increase in total cultural expenditure. Thus, poorer and richer households should have the same share of cultural to total consumption. Our evidence suggests that this is not the case and richer households spend more also in relative terms. This is also suggestive of a luxurious behavior of culture. The by country pattern is reported on figure $\mathrm{A} 1$ of the appendix.

Figure 3 Panel A shows that for LAC (Figure A2 in the appendix presents the results by country), households with one child spend on average $\$ 75$ in culture, while households with two children spend per child \$ $49(98 / 2)$ and those with three spend per child $\$ 31.7$ (95/3). As the number of children increases, the expenditure per child decreases. The reduction between households with three children and with four or more is of a very high magnitude. This variation is too large to be produced by household economies of scale. An alternative interpretation is a kind of reverse causality: poor families have more children, and if poor families spend a lower proportion of their budgets on culture, then this translates into less cultural spending per child.

That is, although there are some economies of scale (or at least spreading of some of the fixed costs) of operating larger households with more members (sharing of housing rent, sharing of children's clothing as they age, a modestly lower marginal cost of feeding one more person relative to the average cost of food per person), the absolute costs of meeting the expenses of larger households is highly likely to become much more burdensome relative to household income than for smaller households, making it much less likely that there is sufficient discretionary income leftover to purchase recreational/entertainment services. This means that one underlying reason for the luxury condition of cultural spending itself is the propensity of poorer households to be populated with more children.

FIGURE 2

AVERAGE ANNUAL CULTURAL EXPENSES BY EXPENDITURE QUINTILE

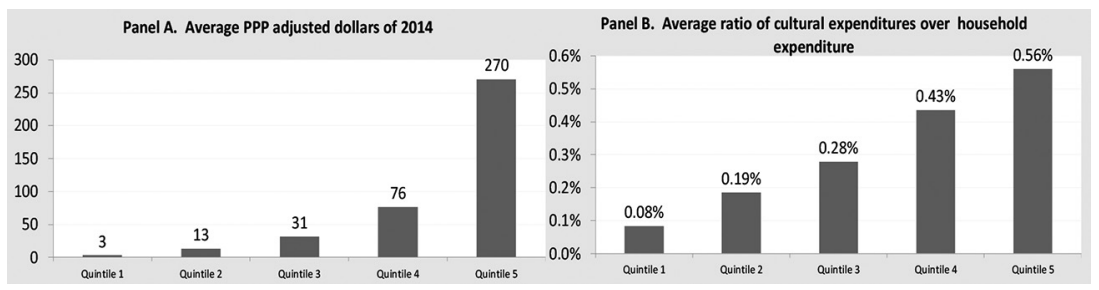


We present in Figure 4 the cultural expenditure pattern by level of education of the household head. Figure A3 in the appendix shows results by country. Here we see another clear pattern. More educated households spend more on absolute terms in cultural goods. Also, they allocate larger shares of their budget to cultural spending. This might be due to more appreciation of culture by educated people or just because more educated people are richer, and culture is a luxury good. The past literature efforts to separate the effects of the (clearly positively related) income and education variables, have almost universally shown the primacy of education, holding income constant (e.g. Seaman, 2006). As noted by an anonymous referee, the enhanced amount of "cultural consumption capital" available to the more educated can reduce the shadow price of generating arts appreciation services from any number of observed visits to a museum or attendance at performances, and is a key underlying reason why there might be more appreciation of culture among the educated, and hence more observed cultural visits and cultural spending among the educated. The next section controls the joint variation of relevant variables.

\section{b. Engel curves}

In Tobit estimations the marginal effects coincide with the estimated coefficients. These estimations are reported in Table 2 for total cultural spending and for three subcomponents: spending in cinemas, theaters, music and dancing

FIGURE 3

AVERAGE ANNUAL CULTURAL EXPENSES BY NUMBER OF CHILDS

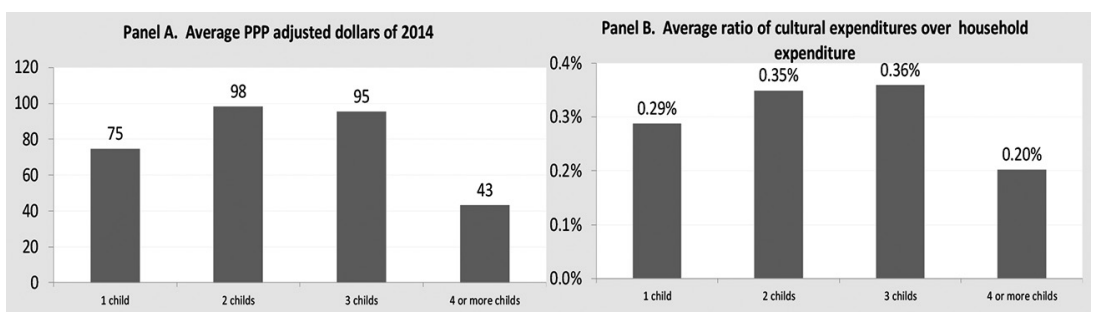

FIGURE 4

AVERAGE ANNUAL CULTURAL EXPENSES BY EDUCATION LEVEL OF THE HOUSEHOLD HEAD

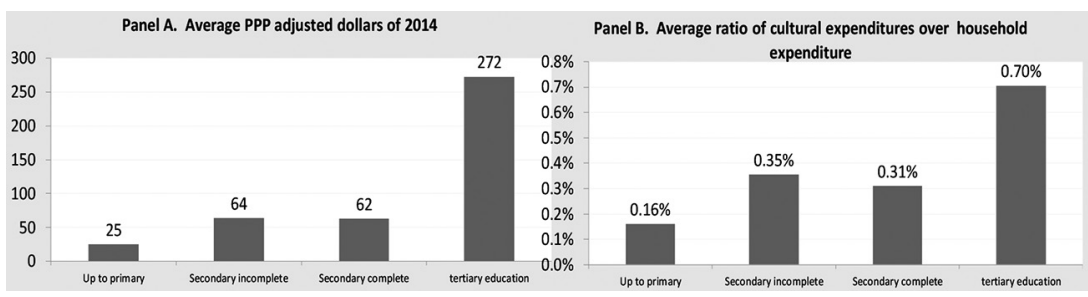


events, spending in sports events and other cultural spending. For most variables, the estimated coefficients have the expected signs and are statistically significant. Per capita expenditure is positive and significant in the determination of cultural goods allocation. Urban households tend to allocate more on cultural spending than rural ones. Households where the female is the household head spend a larger share of their budget in culture in general but less in sports events. The educational level of the household head is positively related with cultural spending, (the omitted educational category is the lower education level, just primary school). The natural logarithm of the number of members on the household is also positive and statistically significant. We only find a statistically significant effect of age in the share of spending in sports. Older household heads spend a lower percentage of their total expenditure in attending sports events.

TABLE 2

ENGLE CURVES ESTIMATION FOR LAC (TOBIT)

\begin{tabular}{|c|c|c|c|c|}
\hline & $\begin{array}{l}\text { Total cultural } \\
\text { spending }\end{array}$ & $\begin{array}{c}\text { Spending } \\
\text { in cinemas, } \\
\text { theaters, } \\
\text { music and } \\
\text { dancing } \\
\text { performances }\end{array}$ & $\begin{array}{l}\text { Spending in } \\
\text { sports events }\end{array}$ & $\begin{array}{c}\text { Other } \\
\text { cultural } \\
\text { spending }\end{array}$ \\
\hline Per capita expenditure (in logs) & $\begin{array}{l}0.01958 * * * \\
(0.00093)\end{array}$ & $\begin{array}{c}0.01995 * * * \\
(0.00121)\end{array}$ & $\begin{array}{l}0.01170 * * * \\
(0.00082)\end{array}$ & $\begin{array}{c}0.01736^{* * * *} \\
(0.00123)\end{array}$ \\
\hline Age of the household head & $\begin{array}{l}-0.00006 \\
(0.00015)\end{array}$ & $\begin{array}{l}-0.00002 \\
(0.00016)\end{array}$ & $\begin{array}{c}0.00018 \\
(0.00020)\end{array}$ & $\begin{array}{l}-0.00021 \\
(0.00029)\end{array}$ \\
\hline Age of the household head squared & $\begin{array}{l}-0.00000 \\
(0.00000)\end{array}$ & $\begin{array}{l}-0.00000 \\
(0.00000)\end{array}$ & $\begin{array}{r}-0.00000 * \\
(0.00000)\end{array}$ & $\begin{array}{l}-0.00000 \\
(0.00000)\end{array}$ \\
\hline Dummy for urban households & $\begin{array}{c}0.01220 * * * \\
(0.00117)\end{array}$ & $\begin{array}{c}0.01737 * * * \\
(0.00166)\end{array}$ & $\begin{array}{c}0.00437 * * * \\
(0.00129)\end{array}$ & $\begin{array}{c}0.00195 \\
(0.00190)\end{array}$ \\
\hline Female household head & $\begin{array}{l}0.00270 * * * \\
(0.00080)\end{array}$ & $\begin{array}{c}0.00390 * * * \\
(0.00091)\end{array}$ & $\begin{array}{c}-0.00279 * * \\
(0.00137)\end{array}$ & $\begin{array}{c}0.00151 \\
(0.00142)\end{array}$ \\
\hline $\begin{array}{l}\text { Household head } \\
\text { education=secondary incomplete }\end{array}$ & $\begin{array}{l}0.00248^{*} \\
(0.00141)\end{array}$ & $\begin{array}{l}0.00278^{*} \\
(0.00162)\end{array}$ & $\begin{array}{l}-0.00171 \\
(0.00212)\end{array}$ & $\begin{array}{c}0.00682 * * * \\
(0.00244)\end{array}$ \\
\hline $\begin{array}{l}\text { Household head } \\
\text { education=secondary complete }\end{array}$ & $\begin{array}{c}0.00683^{* * * *} \\
(0.00112)\end{array}$ & $\begin{array}{l}0.00919 * * * \\
(0.00138)\end{array}$ & $\begin{array}{c}0.00339 * * \\
(0.00145)\end{array}$ & $\begin{array}{l}-0.00144 \\
(0.00177)\end{array}$ \\
\hline Household head education=tertiary & $\begin{array}{c}0.01620 * * * \\
(0.00149)\end{array}$ & $\begin{array}{c}0.02023 * * * \\
(0.00201)\end{array}$ & $\begin{array}{l}0.00620^{* * * *} \\
(0.00175)\end{array}$ & $\begin{array}{l}-0.00014 \\
(0.00198)\end{array}$ \\
\hline Household members (in logs) & $\begin{array}{l}0.01983^{* * * *} \\
(0.00120)\end{array}$ & $\begin{array}{l}0.01798^{* * * *} \\
(0.00146)\end{array}$ & $\begin{array}{c}0.01345^{* * * *} \\
(0.00121)\end{array}$ & $\begin{array}{c}0.02394 * * * \\
(0.00174)\end{array}$ \\
\hline Country Controls & $-0.19814 * * *$ & $-0.21253^{* * *}$ & $-0.15605^{* * *}$ & $-0.28870 * * *$ \\
\hline Observations & $(0.00978)$ & $(0.01363)$ & $(0.00938)$ & $(0.02154)$ \\
\hline
\end{tabular}

Note: Robust standard errors in parentheses. $* * *$ statistically significant at $1 \%$, ** statistically significant at $5 \%$, * statistically significant at $10 \%$. 
The main results of our paper are presented in Figure 5 where we present the by country expenditure elasticities valued at the mean of the countries' cultural share (conditional on positive cultural spending). In the estimations using all LAC countries we find an expenditure elasticity of 2.0. At the country level, the point estimates of the elasticities range from 1.7 (Brazil) to 2.9 (Bolivia). In all the cases, estimates are well above 1 at statistically significant levels. Thus, our results suggest that cultural spending behaves as a luxurious good for the seven LAC countries considered. Figure 6 shows the elasticity for LAC of the three categories we could disaggregate form the data (in Figure A4 we report these disaggregated elasticities by country). The expenditure elasticities are remarkably similar. For spending in cinemas, theatres, music and dancing performances we find an elasticity of 2.0, for spending in sports events we find an elasticity of 1.9 and for spending in other cultural activities we find and elasticity of 2.0. In none of these three cases can we reject the null of an expenditure elasticity of an expenditure elasticity of 2.0 .

FIGURE 5

EXPENDITURE ELASTICITIES

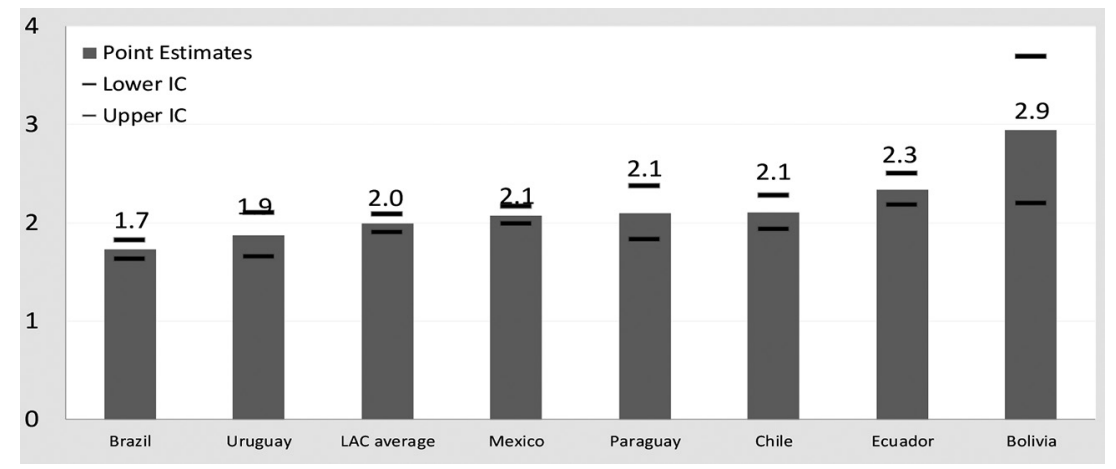

FIGURE 6

DISSAGREGATED EXPENDITURE ELASTICITIES

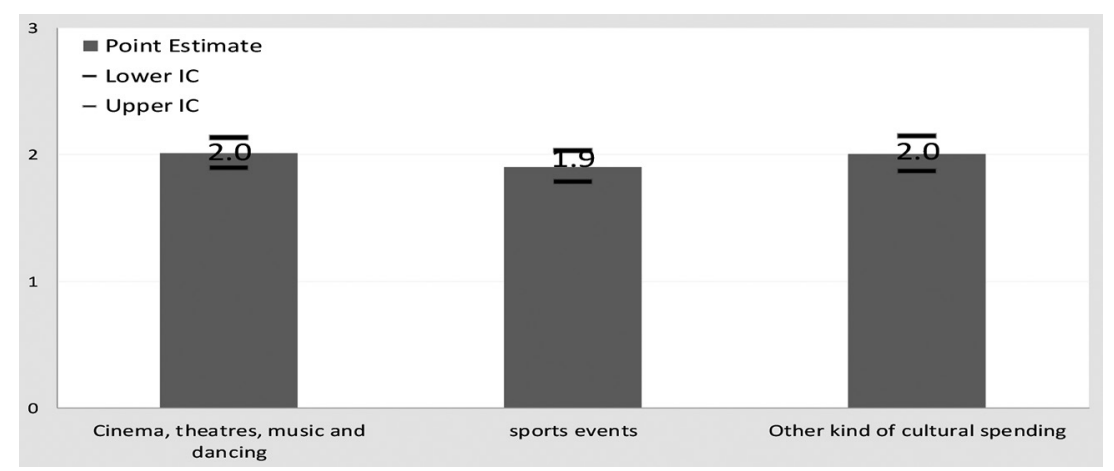




\section{Conclusions}

In this paper, we characterized private spending on culture in seven LAC countries and presented relevant stylized facts. The region shows a low budget assignment to consumption in cultural goods. Chile and Mexico have in relative and absolute terms the largest household cultural spending. Ecuador, Brazil and Paraguay have the lowest cultural spending in relative terms. Within countries there is great heterogeneity in the allocation of budget for cultural activities with more than half of the households with 0 household spending in cultural goods. The country Gini estimates of cultural spending are about two times the Gini estimates for total expenditure.

Most educated and richer household heads spend more in cultural spending both in absolute levels but also as percentage of total household consumption. Even after controlling for the household total expenditure, we find a statistically significant association between the household head education and cultural spending. This suggests that more educated people indeed appreciate more cultural spending and is not only that they invest more in culture because they are richer.

The main result reported is that total consumption spending is positively correlated with the share of cultural spending and with a cultural expenditure elasticity of 2 . In every single country we reject the null of unitary elasticity or less than unitary elasticity corresponding to culture being a necessity. We disaggregate cultural expenditure into three components (spending in cinemas, theatres, music and dancing events, spending in sports events, and spending in other cultural activities) and found their respective elasticities also to be around 2. Therefore, our result that culture is a luxury in LAC is not produced by introduction of some particular form of spending into the culture definition. The reported elasticities are somewhat larger than others reported in studies that use aggregated data and are based on developing countries. Methodologically, an important difference with these studies is that our paper is based on actual spending and cross sections of households that are likely to have more underlying variability in their observations, especially in regions with inequality as high as LAC.

Appreciation of cultural activities is an intrinsically dynamic activity. Higher exposure in the past potentiates future demand. Ateca (2007) suggest two possible channels. Following Becker and Murphy (1988) rational modeling of addiction, Ateca suggests that past cultural experiences are transformed into culture capital. The larger the culture capital, the larger the utility of current consumption of cultural goods. On the other hand, learning by consuming models (Lévy Garboua and Montmarquette, 1996) considers the need to experience culture goods to appreciate it and therefore past consumption is linked to future consumption.

Our finding of culture spending being a luxury has implications for subsiding policy over the business cycle. In downturns, the fall in demand in cultural sectors would be larger than the average economy fall in demand. The temporal effect of culture consumption magnifies and propagates over time the negative 
impacts of short run negative economic shocks. Thus, the luxury condition of culture demand joint with the intertemporal links in culture consumption suggests that governments should strongly consider their promotion policies when the fiscal budget is tighter rather than when the economy is booming. Nevertheless, not all forms of promotion policies are the same since the literature has some evidence that lower priced, closer to home (and more time flexible) art forms often behave in a counter-cycle fashion (for museums see Skinner et al. 2009 and for cinemas see Vogel 2007 who in turn cites Nardone,1982). Finally, we acknowledge that counter-cyclical policy to protect the cultural sector during economic downtowns might be politically difficult to implement.

\section{REFERENCES}

Acerenza, S. and Gandelman, N. (2019). Household education spending in Latin America and the Caribbean: Evidence from income and expenditure surveys, Education Finance and Policy 14(1).

Agnello, R. and Pierce, R. (1996). Financial Returns, Price Determinants, and Genre Effects in American Art Investment. Journal of Cultural Economics, 20 (4): 359-83.

Alliance for the Arts (2009), Recession and the Arts: The Impact of the Economic Downturn on Nonprofit Cultural, New York.

Ateca, V. (2007). Cultural capital and demand, Economics Bulletin, 26 (1): 1-9. Baumol, W. and Bowen, W. (1966). Preforming Arts: The Economic dilemma. New York: Twentieth Century Fund.

Becker, G. and K. Murphy (1988). “A Theory of Rational Addiction”, Journal of Political Economy, 96 (4): 675-700.

Bernat, L., Mora, J. and Zulaga, B. (2012). La Elasticidad Ingreso del Consumo Cultural en Cali. Revista de Economía Institucional, 14 (27): 165-192.

Blundell, R. (1998). Consumer Demand and Intertemporal Allocations: Engel, Slutsky and Firsch', in Steinar Strom (ed.), Econometrics and Economic Theory in the 20th Century: The Ragnar Frisch Centennial Symposium, Cambridge University Press, Econometric Society Monographs 31.

Bonato, L., Gagliardi, F. and Gorelli, S. (1990). The demand for live performing arts in Italy, Journal of Cultural Economics, 14, 41-52.

Browning, H. and Sorrell, A. (1954). Cinemas and Cinema-going in Great Britain. Journal of the Royal Statistical Society, 117: 113-65.

Burton, J.M., Horowitz, R. and Abeles, H. (2000). Learning in and through the arts: The question of transfer. Studies in Art Education, 41 (3), 228-57.

Cameron, S. (1990). The Demand for Cinema in the United Kingdom. Journal of Cultural Economics, 14 (1): 35-47.

Casacuberta, C. and Gandelman, N. (2012). Multiple job holding: the artist's labor supply approach. Applied Economics, 44 (3), 323-337.

Coleman, D. and Iso-Ahola, S. (1993). Leisure and health: The role of social support and self-determination. Journal of Leisure Research, 25 (2), 111-28. 
Dardis, R., Soberon-Ferrer, H. and Patro, D. (1994). Analysis of leisure Expenditures in the United States. Journal of Leisure Research, 26 (4): 309-21.

Diniz, S. and Machado, A. (2011). Analysis of the consumption of artistic-cultural goods and services in Brazil. Journal of Cultural Economics, 35: 1-18.

Dupuis, S. and Smale, B. (1995). An examination of relationship between psychological well-being and depression and leisure activity participation among older adults. Society and Leisure, 18 (1), 67-92.

Ekelund, R.B. Jr, and S. Ritenour (1999). "An exploration of the Beckerian theory of time costs: Symphony concert demand", American Journal of Economics and Sociology, 58: 887-899.

Felton, M. (1992). On the Assumed inelasticity of the Demand for the performing arts. Journal of Cultural Economics, 16 (1): 1-12.

Fernández Blanco, V. and Baños Pino, J. (1997). Cinema Demand in Spain: A Cointegration Analysis. Journal of Cultural Economics, 21: 57-75.

Frey, B. (2002). Creativity, Government and the Arts. De Economist, 150 (4): 363-76.

Frey, B. and Pommerehne, W. (1989). Muses and Markets: Explorations in the Economics of the Arts. Oxford: Basil Blackwell.

Fullerton, D. (1992). On justifications for public support of the arts, Journal of Cultural Economics, 16, 67-82.

Gandelman, N., Serebrisky, T. and Suárez-Alemán, A. (2018). Household spending on transport in Latin America and the Caribbean: Understanding transport expenditure patterns. Documento de Investigación 115, Facultad de Administración y Ciencias Sociales, Universidad ORT Uruguay.

Gapinski, J. (1984). The Economics of Performing Shakespeare. The American Economic Review, 74 (3): 458-66.

Gapinski, J. (1986). The Lively Arts as Substitutes for the Lively Arts. The American Economic Review, 76 (2): 20-25.

Garst, B., Scheider, I. and Baker, D. (2001). Outdoor adventure program participation impacts on adolescent self-perception. Journal of Experiential Education, 24 (1), 41-9.

Ginsburgh, V. and Jeanfils, P. (1999). Long-Term co movements in International markets for Paintings. European Economic Review, 39: 538-48.

Halsey, A. (1972). Leisure. In Halsey, A, Trends in British Society since 1900. London: Mac Millan.

Kelejian, H. and Lawrence, W. (1980). Estimating the Demand for Broadway Theater: A Preliminary Inquiry. In Hedon, W., Shanahan, J. and MacDonald, A. Economic Policy for the Arts, Cambridge: Abt Books Inc.

Leser, C. (1963). Forms for Engel curves. Econometrica, 31: 694-703.

McCain, R. (1995). Cultivation of taste and Bounded Rationality: Some Computer Simulations. Journal of Cultural Economics, 19: 1-15.

Mermiri, T. (2011). "Private investment in culture: the sector in and postrecession", Cultural Trends, 20 (3/4): 257-259.

Moore, Thomas G. (1968). Economics of the American Theater. Duke University Press, Durham, North Carolina. 
Nardone, J.M. (1982). Is the Movie Industry Countercyclical, Cycles, 33 (3).

Peacock, A. (1969). Welfare economics and public subsidies to the arts. Manchester School of Economic and Social Studies, 4.

Reeder, R. and Brown, D. (2005). Recreation, Tourism and Rural well-being. USDA Economic research report number 7.

Schreiner, A.S., Yamamoto, E. and Shiotani, H. (2005). Positive affect among nursing home residents with Alzheimer's dementia: the effect of recreational activity. Aging and Mental health, 9 (2), 129-34.

Seaman, B. (2006). Empirical studies of demand for the performing arts. In V. Ginsburgh and D. Throsby (eds.). Handbook of the economics of art and culture (vol. 1, pp. 416-472). Amsterdam: Elsevier.

Silverstein, M. and Parker, M. (2005). Leisure Activities and Quality of Life among the oldest old in Sweden. Research on Aging, 24 (5).

Skinner, S.J., R.B. Ekelund, Jr. and J. D. Jackson (2009). “Art museum attendance, public funding and the business cycle", American Journal of Economics and Sociology, 68 (2): 491-516.

Spraos, J. (1962). The decline of the Cinema: An Economist's Report. London: Allen and Unwin.

Throsby, D. (1994). A work-preference model of artist behavior. In A. Peacock and I. Rizzo (eds.). Cultural Economics and Cultural Policies, Boston, Springer.

Throsby, D. (2001). Economics and Culture. Cambridge University Press.

Throsby, D. and Withers, G. (1979). The Economics of the Performing Arts. London: Edward Arnold.

Torjman, S. (2004). Culture and recreation: Links to well-being. Caledon Institute of Social Policy.

Vogel, H. L. (2007). Entertainment Industry Economics: A Guide for Financial Analysis, Cambridge University Press, $7^{\text {th }}$ edition.

Withers, G. (1980). Unbalanced growth and the demand for the Performing Arts: An Econometric Analysis. Southern Economic Journal, 46 (3): 735-42.

Working, H. (1943). Statistical laws and family expenditure. Journal of the American Statistical Association, 38: 43-56.

Woronkowicz, J. (2015), "Artists, employment and the Great Recession: A cross-sectional analysis using U.S. Current Population Survey data", Cultural Trends, 24 (2): 154-164.

Zieba, M. (2009). Full-income and price elasticities of demand for German public theatre. Journal of Cultural Economics, 33: 85-108. 


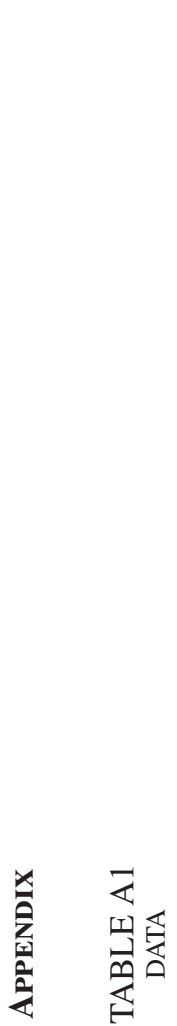

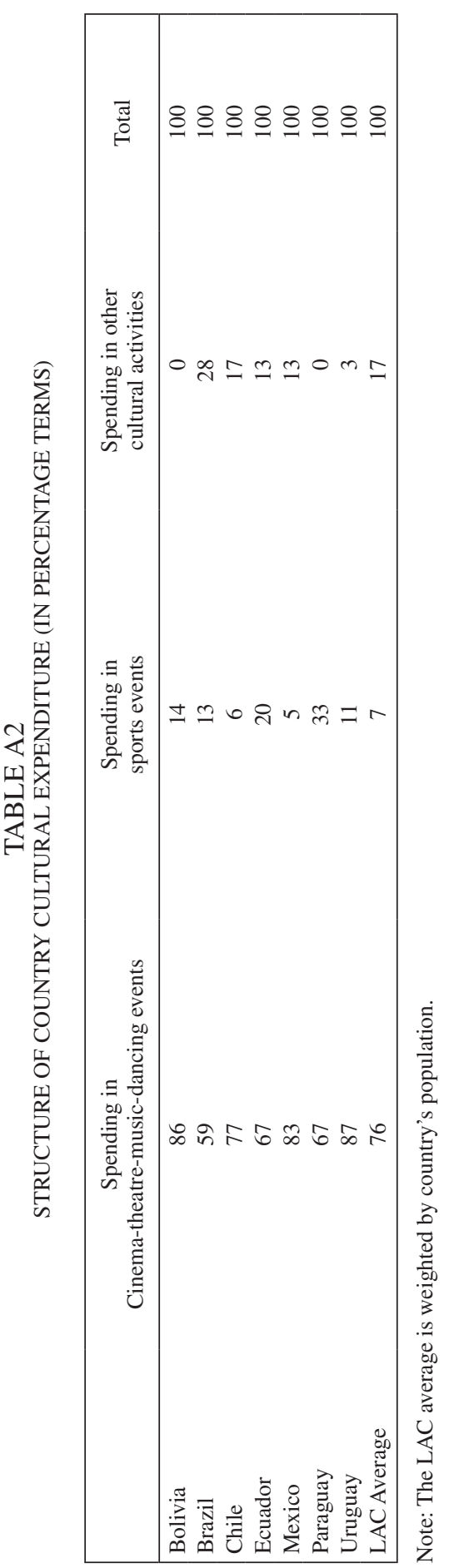




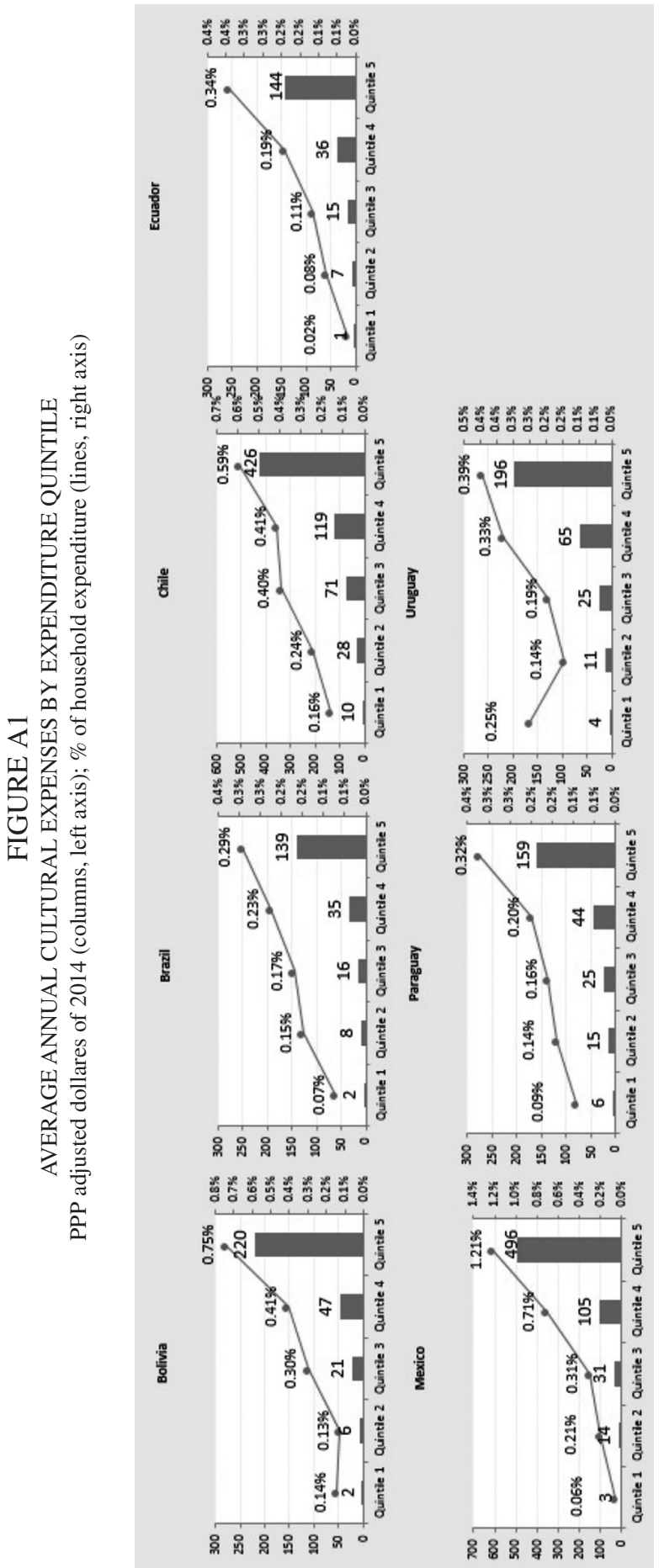




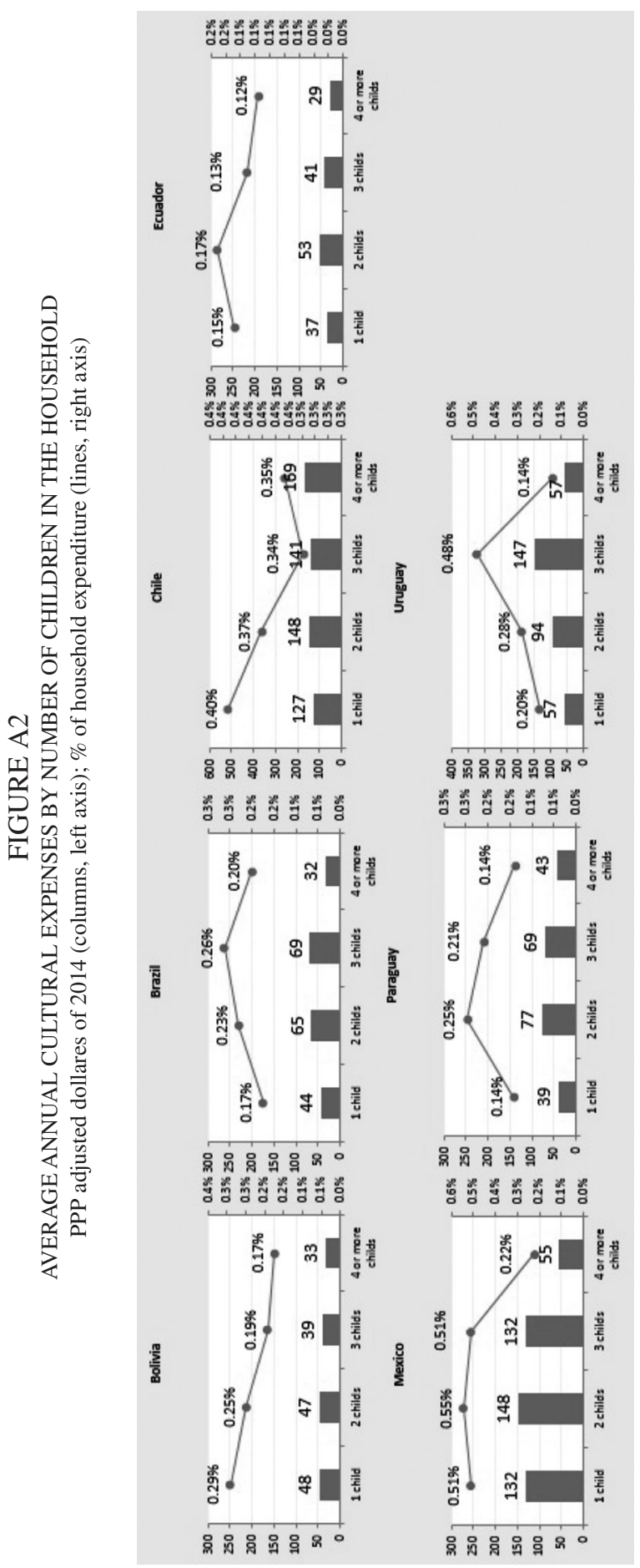




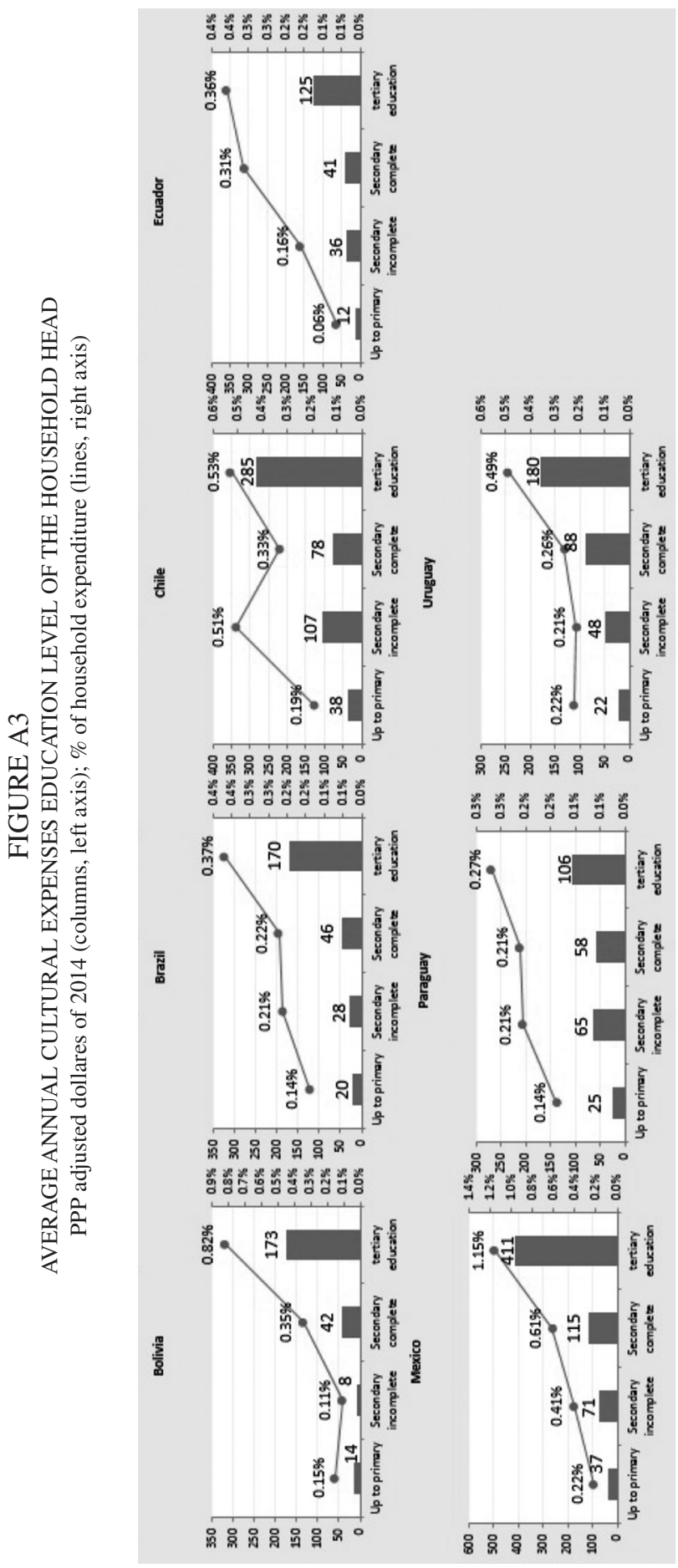


FIGURE A4

EXPENDITURE ELASTICITIES BY COUNTRY AND COMPONENTS

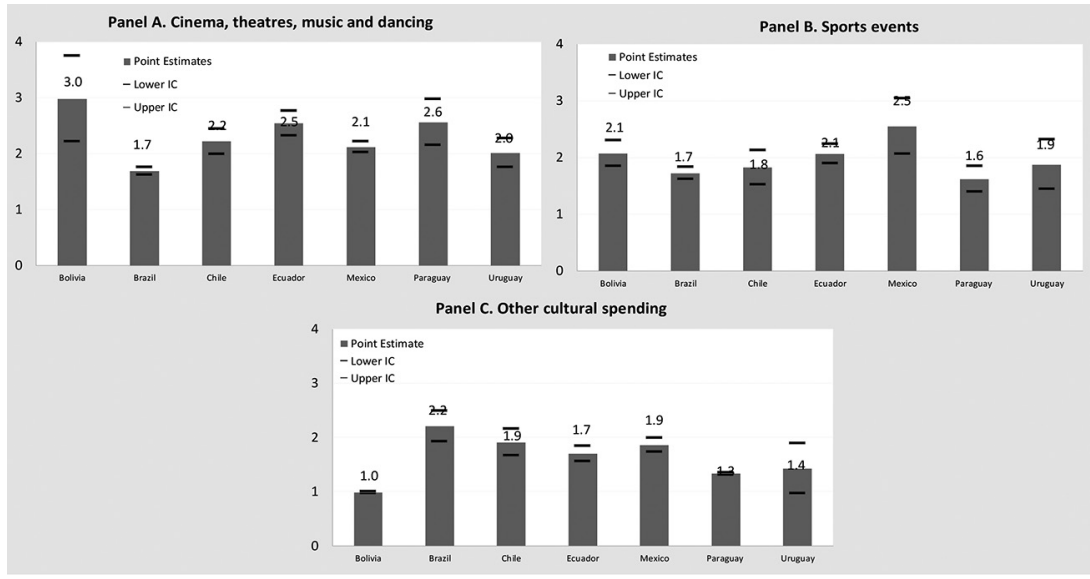

